\title{
Effect of passive ultrasonic irrigation on hard tissue debris removal: a systematic review and meta-analysis
}

\author{
Ana Flávia Almeida BARBOSA ${ }^{(a)}$ \\ Carolina Oliveira de LIMA ${ }^{(a)}$ \\ Luciana Moura SASSONE(a) iD \\ Raissa Dias FARES(b) ${ }^{(\mathrm{D}}$ \\ Tatiana Kelly da Silva FIDALGO(b) iD \\ Emmanuel João Nogueira Leal \\ SILVA $^{(a)}$ iD \\ (a) Universidade do Estado do Rio de Janeiro \\ - UERJ, School of Dentistry, Department of \\ Endodontics, Rio de Janeiro, RJ, Brazil. \\ (b) Universidade do Estado do Rio de Janeiro \\ - UERJ, School of Dentistry, Department of \\ Preventive and Community Dentistry, Rio de \\ Janeiro, RJ, Brazil.
}

Declaration of Interests: The authors certify that they have no commercial or associative interest that represents a conflict of interest in connection with the manuscript.

Corresponding Author:

Emmanuel João Nogueira Leal Silva

E-mail: nogueiraemmanuel@hotmail.com

https://doi.org/10.1590/1807-3107bor-2021.vol35.0123

Submitted: September 22, 2020

Accepted for publication: March 15, 2021

Last revision: May 13, 2021
Abstract: Accumulated hard tissue debris (AHTD) in root canal irregularities may negatively impact adequate root canal disinfection. In light of this, the efficacy of passive ultrasonic irrigation (PUI) to reduce AHTD has been largely studied in in vitro studies, which have adopted different analytic methods of varying accuracy to determine the extent of AHTD more correctly. Therefore, the aim of this study was to compare how well PUI and non-activated irrigation (NAI) systems perform in reducing AHTD during final irrigation protocols, based exclusively on studies whose analyses used microCT scanning. A systematic search of the studies published up to April 2020 was performed using MeSH terms and free terms, in the following databases: PubMed, Scopus, Web of Science, BVS (Lilacs and BBO) and Embase. The inclusion criteria consisted of laboratory studies that evaluated the amount of AHTD, and compared PUI with NAI protocols using microCT analysis. The risk of bias in the selected studies was assessed critically by two reviewers. A meta-analysis was performed using the RevMan software program $(\mathrm{P}<0.05)$, and included studies providing the standardized mean difference (SMD), using a fixed effect model, and adopting a confidence interval of $95 \%$. In all, 3495 studies were identified, three of which met the inclusion criteria. All three were considered as having a low risk of bias. The meta-analysis comparing the ability of PUI and NAI protocols to remove hard tissue debris showed a higher percentage of AHTD reduction $(\mathrm{P}<0.01)$ for PUI, with a confidence interval of 1.41 [0.79, 2.02]. The heterogeneity among the studies was $82 \%\left(\mathrm{I}^{2}\right)$. Considering the limitations of the present study, this systematic review and meta-analysis showed that PUI was more effective than NAI in removing hard tissue debris, based exclusively on studies that used microCT scanning to provide a more precise analysis of the two techniques used. The findings presented in the present study reinforce the concept that PUI can increase residue removal and improve the cleanliness of the root canal in endodontic treatments.

Keywords: X-Ray Microtomography; Systematic Review; Ultrasonics; Root Canal Preparation.

\section{Introduction}

The root canal system has a complex anatomy with areas that cannot be touched mechanically by endodontic instruments, such as isthmuses, fins 
and recesses in oval-shaped canals. ${ }^{1,2}$ Apart from this, the use of endodontic instruments in contact with dentin walls produces dentin debris that accumulates in root canal irregularities and their complexities. ${ }^{3,4}$ Residues such as pulpal tissue, infected dentin debris and microbial biofilm may remain inside the root canal system, and may interfere in the overall quality of root canal filling procedures, potentially contributing to endodontic treatment failure. ${ }^{5,6,7}$ Nevertheless, instrumentation alone cannot provide the complete removal of debris, even more so in the apical areas, where the use of irrigation protocols is key to achieving satisfactory outcomes for debris removal.

The accumulated hard tissue debris (AHTD) within root canal irregularities may be inaccessible to conventional syringe-and-needle non-activated irrigation (NAI) ${ }^{6,8}$ Additional supplementary methods, such as passive ultrasonic irrigation (PUI) using sodium hypochlorite $(\mathrm{NaOCl})$ and/or ethylenediaminetetraacetic acid (EDTA), have been proposed to drive irrigant solutions into these root canal complexities. ${ }^{9,10}$ PUI consists essentially of transmitting energy from an ultrasonically oscillating instrument to the irrigant solutions in the root canal. ${ }^{11}$

Among the different irrigant activation techniques, PUI is widely used. ${ }^{9,12,13}$ Some studies showed that PUI improves the penetration, circulation and flow of the irrigant, thus promoting a significant reduction in AHTD from complex areas of the root canal system. . $^{1314,15}$ Analysis of AHTD removal can be performed with different evaluation methods, including microcomputed tomography (microCT), scanning electron microscopy (SEM), and photomicrography, which can make the comparison of results among the studies more difficult. ${ }^{16}$ Furthermore, many studies that compare PUI and NAI have methodological limitations, such as differences in the volume of irrigant solution, and time of contact of the irrigant inside the root canal. Other studies have found excellent results for the PUI protocol, but did not include a NAI control group to compare the results. ${ }^{17-20}$

A previous systematic review determined the ability of PUI and NAI to reduce AHTD and the smear layer. ${ }^{13}$ However, SEM was used as the analytical tool in this particular review, bearing in mind that this imaging technique has been widely considered a non-trustworthy and non-reproducible method for these purposes in other studies in the literature. ${ }^{21,22}$ Accordingly, the results for the review in question might not be as accurate as those obtained exclusively by microCT, which has proven to be the most precise tool for quantitative and qualitative analysis of hard tissue debris removal in the root canal system. ${ }^{8,23,24}$ Therefore, considering the limitations of the Virdee et al. ${ }^{13}$ study, and the lack of systematic reviews that evaluated the reduction in AHTD using microCT technology, the objective of this study was to compare how well PUI and NAI are able to reduce AHTD using microCT. In this context, this systematic review aimed to answer the following focused question: "Is PUI comparable to NAI for AHTD removal in mature extracted human teeth?"

\section{Methodology}

\section{Protocol and registration}

This systematic review protocol was registered on The Open Science Framework, and is available at the following link: osf.io/e2pux (DOI: 10.17605/OSF. IO/7G8XP). This study was performed following the guidelines of the 2009 PRISMA (Preferred Reporting Items for Systematic Review and Meta-Analysis) statement (http://www.prisma-statement.org).

\section{Search strategy}

The search procedures were performed independently by two examiners (A.F.A.B. and C.O.L.). The PubMed, Scopus, Web of Science, BVS (Lilacs and BBO) and Embase electronic databases were searched for studies published up to April 2020 , with no restrictions on language or year. The electronic search strategy was developed using the most frequently cited descriptors in previous publications on this topic, combining Medical Subject Heading terms (MeSH) and text words $(\mathrm{tw})$. The following terms were combined for each database: "Ultrasonic irrigation," "Ultrasonic activation," "Ultrasonic therapy," "Ultrasonics," "Ultrasonic*," "Debris," "Hard tissue debris," and "Smear layer." The Boolean operators "AND" and "OR" were applied to combine the terms and create the search strategy. The search strategies defined 
for each database are detailed in Table 1 . No filters or limits were applied in the searches. The setup alerts were programmed in all the databases used. A complementary screening of the references of the selected studies was performed, and a hand search was performed in the Journal of Endodontics and the International Endodontic Journal to find any additional studies that did not appear in the primary database search. Articles from different sources were imported to the EndNote Web reference manager (EndNote $\left.{ }^{\mathrm{TM}}\right)$, to catalogue the references and automatically remove duplicate records.

\section{Eligibility criteria}

Studies that evaluated the amount of AHTD and compared the PUI with the NAI protocol were included. The eligibility criteria was based on the PICOS strategy (PRISMA-P 2016), as follows:

a. Population (P): Mature human teeth;

b. Intervention (I): PUI;

c. Comparison (C): NAI;

d. Outcome (O): AHTD;

e. Study design (S): laboratory studies.
Studies that did not use microCT analysis were excluded, as well as those that did not use NAI as a control group, that had no standardized root canal preparation, and/or that did not use the same volume, composition, concentration or contact time of irrigant solutions for the NAI and PUI groups. Reviews, letters, opinion articles, case reports, serial cases, and studies that did not perform the chemo-mechanical step were also excluded.

\section{Selection of the studies}

Two authors (A.F.A.B. and C.O.L.) examined the titles and abstracts of the studies independently, and made a selection among those retrieved. The full text was accessed when the abstract and titles alone were not enough to determine the inclusion or exclusion of a particular study. The second stage of the selection consisted of reading the full texts, and determining whether the respective study would be included, based on the eligibility criteria using the PICOS strategy. In the event of a disagreement between the two examining authors regarding the inclusion of certain studies, the issue would be resolved

Table 1. Search strategy for the databases.

\begin{tabular}{|c|c|c|}
\hline Database & Search strategy & Findings \\
\hline \multirow{3}{*}{ Pubmed } & $\begin{array}{c}\text { \# } 1 \text { ((((Ultrasonic irrigation[Title/Abstract]) OR ultrasonic activation[Title/Abstract]) OR ultrasonic } \\
\text { therapy[Title/Abstract]) OR ultrasonic therapy[MeSH Terms]) OR ultrasonic*[Title/Abstract]) OR } \\
\text { ultrasonics[MeSH Terms] }\end{array}$ & 75,386 \\
\hline & $\begin{array}{c}\text { \#2 }(((\text { debris[Title/Abstract]) OR hard tissue debris[Title/Abstract]) OR smear layer[MeSH Terms] }) \\
\text { OR smear layer[Title/Abstract] }\end{array}$ & 21,243 \\
\hline & \# 1 AND \# 2 & 574 \\
\hline \multirow{3}{*}{ Scopus } & $\begin{array}{c}\text { \# } 1 \text { TITLE-ABS ( "Ultrasonic irrigation" OR "Ultrasonic activation" OR "Ultrasonic } \\
\text { therapy" OR ultrasonic* OR ultrasonics) }\end{array}$ & 201,692 \\
\hline & \#2 TITLE-ABS (debris OR "hard tissue debris" OR "smear layer") & 82,55 \\
\hline & \# 1 AND \# 2 & 846 \\
\hline \multirow{3}{*}{ Web of science } & $\begin{array}{c}\text { \#1 TS }=\text { (“Ultrasonic irrigation" OR "Ultrasonic activation" OR "Ultrasonic therapy" OR } \\
\text { Ultrasonic* OR Ultrasonics) }\end{array}$ & 52,128 \\
\hline & \#2 TS=(Debris OR "Hard tissue debris" OR "Smear layer" OR "Smear layer") & 64,193 \\
\hline & \# 1 AND \# 2 & 763 \\
\hline \multirow{3}{*}{ BVS (Lilacs and BBO) } & $\begin{array}{c}\text { \#1 (tw:("ultrasonic irrigation" OR "ultrasonic activation" OR "ultrasonic therapy" OR } \\
\text { ultrasonics OR ultrasonic*) }\end{array}$ & 7,632 \\
\hline & \#2 (tw:(debris OR "hard tissue debris" OR "smear layer") & 707 \\
\hline & \# 1 AND \# 2 & 63 \\
\hline \multirow{3}{*}{ Embase } & $\begin{array}{l}\text { \#1 "Ultrasonic irrigation": ab,ti OR "Ultrasonic activation": ab,ti OR "Ultrasonic therapy":ab,ti } \\
\text { OR "Ultrasonic therapy"/exp OR Ultrasonic*:ab,ti OR "Ultrasonics"/exp }\end{array}$ & 227,175 \\
\hline & \#2 Debris:ab,ti OR "Hard tissue debris":ab,ti OR "Smear layer":ab,ti OR "Smear layer"/exp & 87,747 \\
\hline & \# 1 AND \# 2 & 1,249 \\
\hline
\end{tabular}


consensually, and, if the two authors still failed to reach an agreement, the matter would be decided by a third experienced author (E.J.N.L.S). Duplicate studies in the database search were considered only once.

\section{Data extraction}

Two authors (A.F.A.B. and C.O.L.) collected the data independently from the included studies. Eventual disagreements regarding data collection were resolved consensually between the two authors, and, whenever no agreement could be reached, a third experienced author would decide (E.J.N.L.S). Information regarding publication (author and publication year), financial support, sample size, control group, amount of irrigant solution and statistical analysis were extracted. In case of missing data, up to three attempts were made by email to contact the respective authors.

\section{Quality assessment}

Each study selected was evaluated independently by two authors (A.F.A.B. and C.O.L.), in relation to inner methodological risk of bias.

As for the laboratory studies, a quality assessment was adopted, with adaptations used in previous systematic reviews. ${ }^{25,26,27}$ The following parameters were considered for the quality assessment of the studies included: a) sample size calculation, b) samples with similar conditions, c) control group, d) standardization of procedures, e) statistical analysis, and $\mathrm{f}$ ) other risks of bias. In domain 1 , the study was considered as having a low risk of bias whenever the sample size was calculated and described in the methodology section. In domain 2, the samples were considered similar if the same group of teeth had been used for the AHTD evaluation. Domain 3 evaluated whether the procedures in the control group (NAI) were similar to those of the PUI group, such as root canal preparation, similar volume, type of irrigant and depth of needle insertion. In domain 4 , the low risk of bias of a study indicated NAI and PUI groups using standardized procedures, such as having the same instrument for root canal preparation, the same irrigant, the same volume and concentration of irrigant, and the same needle depth for both groups. In domain 5, there was low risk of bias when the statistical analysis was performed with the proper tests. Finally, in domain 6 , the study was deemed as having low risk of bias if the irrigant used was similar to that used in clinical conditions, and if there was an industry involved in the sponsorship.

During the quality assessment, each parameter for all studies included was judged as having "low," "high," or "unclear" risk of bias. If a given study failed to match the aforementioned respective criteria in any said domain, it would be considered as having a high risk of bias for that given domain. Two independent authors analyzed the manuscripts included (A.F.A.B. and C.O.L.). In the event of a disagreement between the authors, the issue would be resolved by a third author (E.J.N.L.S.). If one or more parameters were considered "unclear," up to three attempts were made to contact the author of that study by email to obtain the information needed to ascertain risk of bias of that domain or domains, on an adequate basis.

Each of the six previously described domains was evaluated one at a time in each study, and color coded as follows: low risk of bias (green); high risk of bias (red); unclear (yellow). The general determination of the individual risk of bias of each study was designed as follows: studies with 5 or more green markers were considered as having a low risk of bias; 4 green markers meant moderate risk of bias; 3 green markers or fewer involved high risk of bias.

\section{Meta-analysis}

Quantitative analysis was carried out on the studies that provided data on the percentual reduction of AHTD, and the number of specimens used per group. The meta-analysis was presented as a standardized mean difference (SMD), with a fixed effect model, and a confidence interval of $95 \% .^{28}$ The meta-analysis was performed using the RevMan software program (version 5.2; the Nordic Cochrane Centre, the Cochrane Collaboration, 2012, Copenhagen, Denmark). The number of samples and the differences in the percentual reduction of AHTD between the groups were obtained, and the results of the meta-analysis were presented using a forest plot. The heterogeneity among the studies was tested using the Higgs index $\left(\mathrm{I}^{2}\right)$, and a forest plot was generated for these comparisons. 


\section{Results}

\section{Selection of studies}

Figure 1 shows the flow diagram of the search strategy. Initially, the search resulted in 3,495 studies published in the relevant databases. Of these, 1,725 were excluded due to duplicity. Analysis of titles and abstracts of the remaining 1,770 eligible papers culminated in the selection of 171 suitable, published studies. The main reason for rejection was the failure to meet the inclusion criteria, especially in relation to the lack of microCT analysis of AHTD. After a comprehensive reading, 157 studies were excluded due to absence of a microCT analysis; 9 due to absence of a NAI group; and 2 due to absence of human teeth. At the end, a total of 3 studies were selected for the present systematic review. The references of the selected studies were searched electronically, and then hand-searched, but no further articles were found. Since the two independent reviewers agreed upon the studies that were included, at every step of the selection process, there was no need for the third author to intervene.

\section{Characteristics of the included studies}

The data collected from the 3 included studies ${ }^{29-31}$ are summarized in Table 2. Sample size calculations
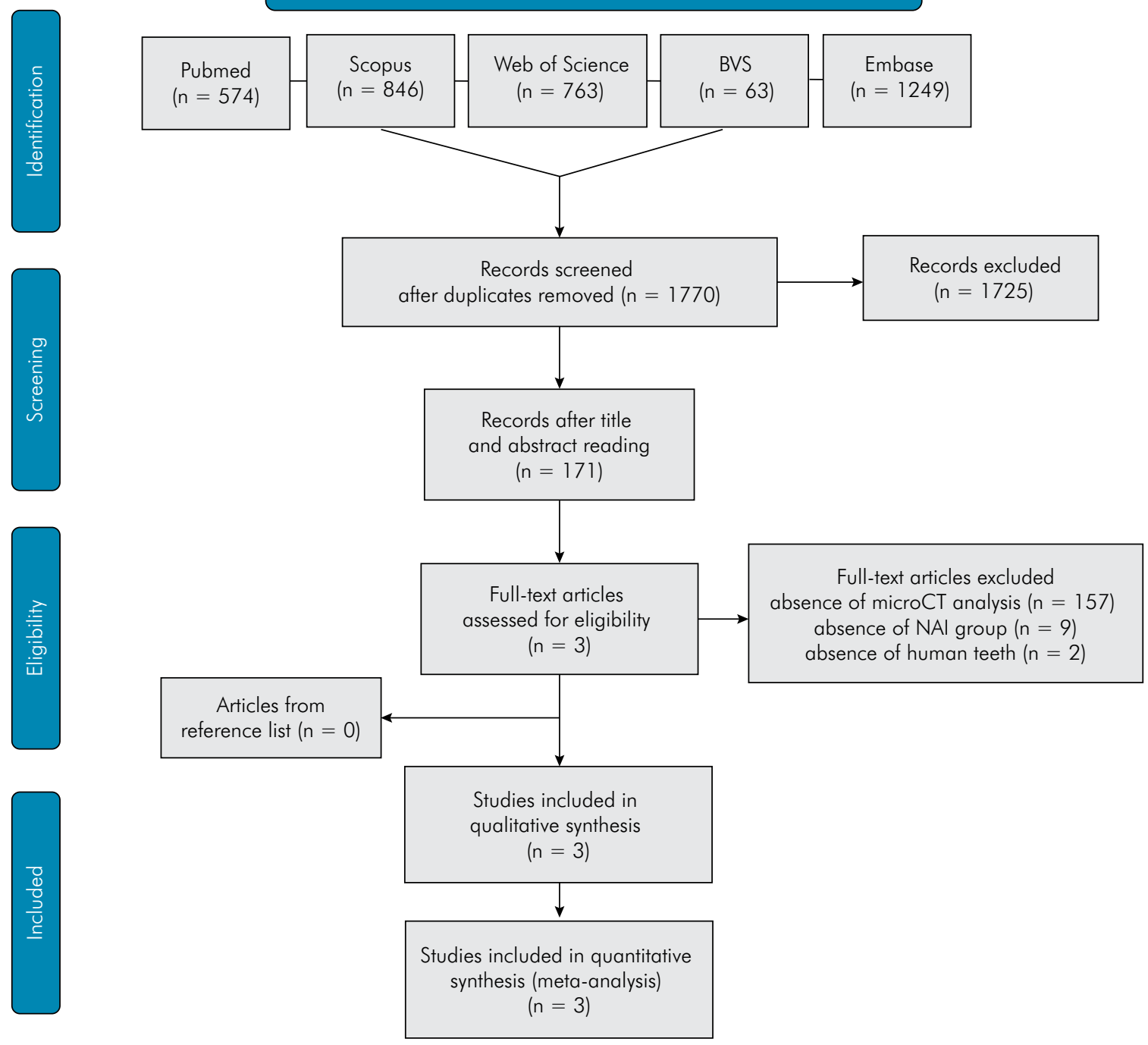

Figure 1. Flow diagram of the literature search and included studies. 
were performed in two of the studies. ${ }^{29,30}$ The study by Zhao et al. ${ }^{31}$ did not perform any sample size calculation, thus justifying the high risk of bias stipulated in domain 1 . All studies were evaluated in relation to the percentual volume of AHTD using microCT analysis, in mandibular molars. Moreover, all the studies presented NAI and PUI groups, and all used the same procedures for both groups, such as using instruments of the same tip diameter and taper in root canal preparation, and the same volume of irrigant and depth of the needle. One of the three studies chose distilled water as the irrigating solution to increase AHTD formation in root canal preparation, and did not use EDTA during the final irrigation, ${ }^{30}$ while the other two studies used sodium hypochlorite $(\mathrm{NaOCl})$ during all the steps of the endodontic treatment, and also used EDTA during the final irrigation procedures. ${ }^{23,29}$ This may justify considering the study as having a high risk of bias in this particular domain (other risk of bias). Nonetheless, all three studies ${ }^{29,30,31}$ were considered as having a low risk of bias. The results are described in Figure 2.

\section{Summary measures and meta-analysis}

The three studies selected ${ }^{29-31}$ reported quantitative results that allowed a quantitative analysis to be conducted. The meta-analysis was performed on how well PUI and NAI were able to reduce AHTD in the root canals. This was determined by considering the means and standard deviations in the percentual reduction of AHTD. Figure 3 shows the forest plot of the pooled comparison between PUI and NAI, which demonstrated a higher percentage of AHTD reduction ( $p<0.00001)$ for PUI, with an SMD, and a confidence interval of $1.41[0.79,2.02]$. The heterogeneity among the studies was $82 \%\left(\mathrm{I}^{2}\right)$.

\section{Discussion}

The meta-analysis showed that the PUI irrigation protocol can reduce greater percentages of AHTD from root canals than the NAI group. This finding can be attributed to the studies' being performed on mandibular molars, which present isthmuses and/or "C-shaped" root canals, hence having a more complex anatomy. Studies on the anatomical complexities of the mesial roots of mandibular molars have shown a prevalence of isthmuses of approximately $80 \%$ between 3-6 $\mathrm{mm}$ from the apex. ${ }^{32}$ These anatomical structures can retain debris from instrumentation. ${ }^{33}$ The PUI protocol has been described as an excellent auxiliary activation method especially in root canal irregularities and isthmuses, ${ }^{29,34}$ since the transmission of energy caused by ultrasonic files induces the stream and cavitation of the irrigation solution, thereby eliminating the vapor lock. ${ }^{11}$ This induction should be further researched to determine whether these results are similar when dealing with teeth having simpler anatomies, considering that most studies with these types of teeth have found that PUI has little or no impact on the general outcome of endodontic treatment. ${ }^{35}$

All the studies selected in this systematic review ${ }^{29,30,31}$ performed the root canal preparation with single-use instruments of similar taper and tip size, thus helping to make the comparison. Regarding chelating agents, previous studies showed an additional effect of EDTA in removing AHTD. ${ }^{17,36}$ In this systematic review, the irrigation with a chelating agent (EDTA) was found to be performed in $\mathrm{two}^{29,31}$ of the three selected studies.

The study by Leoni et al. ${ }^{30}$ showed a $94.1 \%$ reduction in AHTD in the root canals following instrumentation with PUI. This result is considerably higher than that of the other studies included. ${ }^{29,31}$ This difference may be attributed to the irrigation in root canal preparation performed with $\mathrm{NaOCl}$ and EDTA at $2 \mathrm{~mm}$ from the working length in two of the studies. On the other hand, the irrigant of choice in the study by Leoni et al. ${ }^{30}$ was distilled water, and the irrigation was performed only at the orifice level, and done deliberately to provide greater formation of AHTD after root canal preparation, according to the authors. This methodological difference can explain the greater formation and accumulation of AHTD after root canal preparation, which can influence the calculation of the percentual reduction in AHTD after the final irrigation protocol. However, the percentage of AHTD reduction in all the studies included presented similar values in the NAI group. ${ }^{29,30,31}$ In this case, Leoni et al. ${ }^{30}$ did not 
Table 2. Qualitative analysis and characteristics of the included studies.

\begin{tabular}{|c|c|c|c|c|c|c|c|}
\hline $\begin{array}{l}\text { Author, year, } \\
\text { country (type) }\end{array}$ & Funding source & Tooth type & $\begin{array}{c}\text { Group/ Sample } \\
\text { size }\end{array}$ & $\begin{array}{l}\text { PUI Protocol (final } \\
\text { irrigation) }\end{array}$ & NAI Protocol & Outcome & Conclusion \\
\hline \multirow{7}{*}{$\begin{array}{l}\text { Leoni et al. } \\
2017, \text { Brazil } \\
\text { (in vitro) }\end{array}$} & \multirow{7}{*}{$\begin{array}{c}\text { The research } \\
\text { was supported } \\
\text { by CAPES and } \\
\text { FAPESP }\end{array}$} & \multirow{7}{*}{$\begin{array}{c}\text { Mandibular } \\
\text { molars with } \\
\text { complete } \\
\text { isthmus }\end{array}$} & Control & $\begin{array}{l}\text { A total of } 5.5 \mathrm{~mL} \text { of } \\
2.5 \% \mathrm{NaOCl} \text { was used } \\
\text { per canal during a } \\
1 \text {-min activation time } \\
\text { (three cycles of } 20 \mathrm{~s} \text { ). }\end{array}$ & $\begin{array}{c}\text { A total of } 5.5 \mathrm{~mL} \\
\text { of } 2.5 \% \mathrm{NaOCl} \\
\text { was flushed into the } \\
\text { canal where it sat for } \\
2 \text { min. }\end{array}$ & $\begin{array}{l}\text { Reduction } \\
\text { of AHTD }\end{array}$ & \multirow{7}{*}{$\begin{array}{l}\text { The PUI technique } \\
\text { and XP-Endo } \\
\text { Finisher instrument } \\
\text { were associated } \\
\text { with significantly } \\
\text { lower levels of } \\
\text { AHTD, compared } \\
\text { with conventional } \\
\text { irrigation and } \\
\text { the modified SAF } \\
\text { system protocol. }\end{array}$} \\
\hline & & & $\mathrm{NAI}(\mathrm{n}=10)$ & At $2 \mathrm{~mm}$ from the $\mathrm{WL}$ & At $2 \mathrm{~mm}$ from the $\mathrm{WL}$ & PUI $94.1 \%$ & \\
\hline & & & & $\begin{array}{l}\text { The total time for each } \\
\text { irrigation procedure } \\
\text { was } 2 \text { min. }\end{array}$ & $\begin{array}{l}\text { Did not use EDTA } \\
\text { during final irrigation } \\
\text { protocol }\end{array}$ & $\begin{array}{c}\mathrm{XPF} \\
89.7 \%\end{array}$ & \\
\hline & & & Experimental & $\begin{array}{c}\text { Did not use EDTA } \\
\text { during final irrigation } \\
\text { protocol. }\end{array}$ & & NAI $45.7 \%$ & \\
\hline & & & PUI $(n=10)$ & & & SAF $41.3 \%$ & \\
\hline & & & $\operatorname{SAF}(n=10)$ & & & & \\
\hline & & & $\begin{array}{l}\text { XP Endo Finisher } \\
\quad(n=10)\end{array}$ & & & & \\
\hline \multirow{7}{*}{$\begin{array}{l}\text { Rödig } \\
\text { et al. 2019, } \\
\text { Germany, } \\
\text { (in vitro) }\end{array}$} & \multirow{7}{*}{$\begin{array}{l}\text { The research } \\
\text { was supported } \\
\text { by the German } \\
\text { Research } \\
\text { Foundation }\end{array}$} & \multirow{7}{*}{$\begin{array}{l}\text { Mandibular } \\
\text { molars with } \\
\text { isthmus in } \\
\text { the apical } \\
\quad \text { third }\end{array}$} & Control & $\begin{array}{l}\text { A total of } 5 \mathrm{~mL} \text { of } 1 \% \\
\mathrm{NaOCl} \text { was used per } \\
\text { canal during a } 1 \text {-min } \\
\text { activation time, and } \\
5 \mathrm{~mL} 15 \% \text { EDTA was } \\
\text { activated for } 20 \mathrm{~s} \text { (total } \\
\text { of four cycles of } 20 \mathrm{~s} \text { ). }\end{array}$ & $\begin{array}{l}\text { A total of } 5 \mathrm{~mL} \text { of } \\
1 \% \mathrm{NaOCl} \text { was used } \\
\text { per canal. Instead } \\
\text { of being activated, } \\
\text { the irrigant solutions } \\
\text { were left undisturbed. }\end{array}$ & $\begin{array}{l}\text { Reduction } \\
\text { of AHTD }\end{array}$ & \multirow{7}{*}{$\begin{array}{l}\text { Sonically and } \\
\text { ultrasonically } \\
\text { activated irrigation } \\
\text { did not increase } \\
\text { debris reduction } \\
\text { compared with } \\
\text { conventional } \\
\text { irrigation. }\end{array}$} \\
\hline & & & $\mathrm{NAI}(\mathrm{n}=10)$ & At $2 \mathrm{~mm}$ from the $\mathrm{WL}$ & At $2 \mathrm{~mm}$ from the $\mathrm{WL}$ & PUI 66.8\% & \\
\hline & & & & $\begin{array}{l}\text { The total time for each } \\
\text { irrigation procedure } \\
\text { was } 5 \text { min. }\end{array}$ & $5 \mathrm{~mL}$ 15\% EDTA & ED $56.9 \%$ & \\
\hline & & & Experimental & & $\begin{array}{l}\text { The total time for } \\
\text { each irrigation } \\
\text { procedure was } 5 \text { min }\end{array}$ & EA $54.1 \%$ & \\
\hline & & & $\begin{array}{l}\text { Endo Activator } \\
\text { (EA) }(n=10)\end{array}$ & & & $\mathrm{NAI} 44.1 \%$ & \\
\hline & & & $\begin{array}{c}\text { Eddy (ED) } \\
(\mathrm{n}=10)\end{array}$ & & & & \\
\hline & & & PUI $(n=10)$ & & & & \\
\hline \multirow{8}{*}{$\begin{array}{l}\text { Zhao et al., } \\
\text { 2019, China, } \\
\text { (in vitro) }\end{array}$} & \multirow{8}{*}{$\begin{array}{l}\text { This study was } \\
\text { financially } \\
\text { supported by } \\
\text { the National } \\
\text { Natural } \\
\text { Science } \\
\text { Foundation of } \\
\text { China }\end{array}$} & \multirow{8}{*}{$\begin{array}{l}\text { Mandibular } \\
\text { molars with } \\
\text { C-shaped } \\
\text { canals }\end{array}$} & Control & $\begin{array}{l}\text { A total of } 8 \mathrm{~mL} \text { of } 2 \% \\
\mathrm{NaOCl} \text { was used per } \\
\text { canal during a } 1 \text {-min } \\
\text { activation time (three } \\
\text { cycles of } 20 \mathrm{~s} \text { ). }\end{array}$ & $\begin{array}{l}\text { A total of } 8 \mathrm{~mL} \text { of } \\
\mathrm{NaOCl} 2 \% \text { was } \\
\text { allowed to remain in } \\
\text { the canal for } 1 \mathrm{~min} \\
\text { (three cycles of } 20 \mathrm{~s} \text { ). }\end{array}$ & $\begin{array}{l}\text { Reduction } \\
\text { of AHTD } \\
\text { (RB) }\end{array}$ & \multirow{8}{*}{$\begin{array}{l}\text { PUI and XP-F } \\
\text { irrigation removed } \\
\text { more debris than } \\
\text { NAl when using } \\
\text { the RB system. }\end{array}$} \\
\hline & & & $\mathrm{NAI}(\mathrm{n}=10)$ & At $1 \mathrm{~mm}$ from the $\mathrm{WL}$ & At $1 \mathrm{~mm}$ from $\mathrm{WL}$ & $\begin{array}{c}\text { XPF } \\
68.4 \%\end{array}$ & \\
\hline & & & & $\begin{array}{c}2 \mathrm{~mL} \text { of } 17 \% \text { EDTA (not } \\
\text { activated) }\end{array}$ & $\begin{array}{c}2 \mathrm{~mL} \text { of } 17 \% \text { EDTA } \\
\text { (not activated) }\end{array}$ & PUI $64.2 \%$ & \\
\hline & & & & & & NAl $43.4 \%$ & \\
\hline & & & Experimental & & & $\begin{array}{l}\text { Reduction } \\
\text { of AHTD } \\
\text { (XPS) }\end{array}$ & \\
\hline & & & $\begin{array}{c}\text { XP Endo } \\
\text { Finisher }(n=10)\end{array}$ & & & $\begin{array}{c}\text { XPF } \\
63.1 \%,\end{array}$ & \\
\hline & & & $\mathrm{PUI}(\mathrm{n}=10)$ & & & PUI 77.3\% & \\
\hline & & & & & & NAI $57.1 \%$ & \\
\hline
\end{tabular}




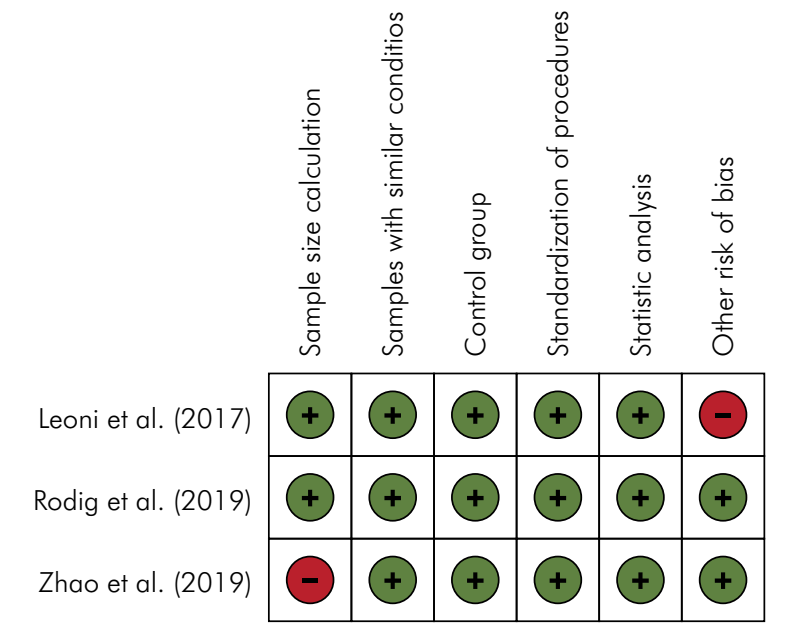

Figure 2. Quality assessment of the included studies.

find greater AHTD reduction values in comparison with the other studies. ${ }^{29,31}$ This could be because NAI was not able to reach the isthmuses in mandibular molars completely. ${ }^{30}$ Although irrigation during root canal preparation was performed with distilled water, which does not simulate clinical conditions, all the procedures in the study by Leoni et al. ${ }^{30}$ were standardized between the groups (same irrigant, same volume of irrigant, depth of the needle and root canal preparation procedures), a strategy which allows comparison of the evaluated groups (PUI and NAI). Therefore, only the other risk of bias domain was considered as having a high risk of bias.

Although these studies are very similar, as stated before, there are differences that may justify the heterogeneity in their results $(82 \%)$, such as the concentration and type of irrigating solution $(\mathrm{NaOCl}$ and distilled water), and the power settings of the ultrasonic devices and tips used. This highlights the relevance of standardizing experimental protocols to allow a more precise analysis of the various techniques applied. Although the $\mathrm{NaOCl}$ concentrations during final irrigation protocols were different among the studies (ranging from 1 to $2.5 \%$ ), it is noteworthy to point out that the removal of AHTD does not seem to be a purely chemical phenomenon, but rather one with a strong physical component. ${ }^{37,38}$

A previous systematic review that used SEM analysis ${ }^{13}$ to evaluate the removal of debris with different activation techniques, demonstrated that PUI improved debris removal in the middle third only when compared with NAI. However, the conventional SEM is a non-trustworthy and non-reproducible method for evaluating AHTD removal. ${ }^{21,22}$ The process of mounting, sectioning and gold sputtering the teeth could potentially affect the remaining debris or smear layer on the root canal walls. Moreover, root canal areas not touched during instrumentation may have been erroneously scored in those studies as areas of removed smear layer. ${ }^{21} \mathrm{In}$ addition, another clear limitation of this method is that the evaluation is always subjective, qualitative and operator-dependent. ${ }^{22}$ On the other hand, the present study was based exclusively on published studies that used microCT analysis to compare PUI and NAI in their methodology. This is why so few studies were included in this review. It is important to emphasize that all three selected studies were considered as having a low risk of bias, and were well designed. ${ }^{29,30,31}$ These studies presented some similar methodological conditions; namely, they all used the same tip diameter and taper of instruments in the root canal preparation, and were performed on mandibular molars.

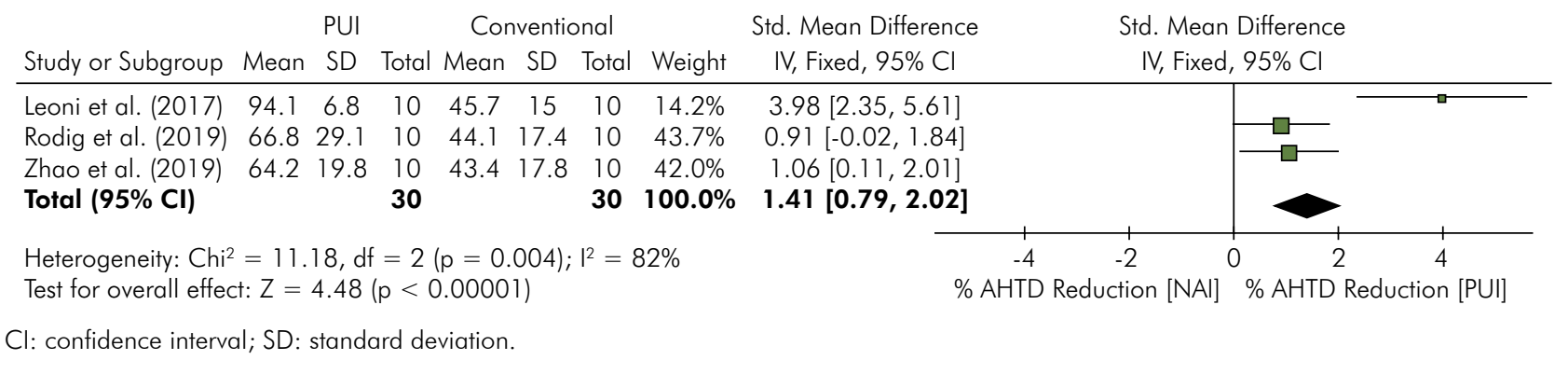

Figure 3. Forest plots of the pooled analysis comparing PUI and NAI. 
The methodology in many previous studies did not include an NAI group, in which the traditional technique with syringes and needles was applied and used as a reference for the comparison. ${ }^{18,20}$, This flaw actually compromises any possibility of realistically assessing what advantages PUI may offer over the traditional irrigation protocol, since the studies lacking this comparison are likely to find superior results for PUI simply because the total volume of irrigating solution is greater after agitation, regardless of any actual influence wielded by the traditional protocol. In light of this, studies that do not offer the proper basis for an accurate comparison, as stated previously, should be considered unreliable in ascertaining the superiority of PUI performance over the traditional irrigation protocol. This is a critical issue, since our search was finally left with only three studies that met the inclusion criteria, and one of the main reasons for exclusion of the rest was that there was no adequate control group.

One limitation of the present systematic review is the reduced number of eligible studies. Further studies with an improved study design and proper methods of analysis (microCT) are required to raise the power of the external validity. The heterogeneity among the studies was high (82\%), and the forest plot demonstrates that high heterogeneity was attributed to the study by Leoni et al..$^{30}$ It is suggested that irrigation with distilled water chosen by Leoni et al. - unlike $\mathrm{NaOCl}$ as the irrigating solution and EDTA as the chelating agent chosen by the other authors was responsible for the overall heterogeneity among the studies. In relation to the microCT analysis, previous in vitro studies have found that this is the most precise tool for quantitative and qualitative evaluation of AHTD and apically extruded debris within the root canal system. ${ }^{8,23,24,39}$

Studies involving PUI are based mainly on its use during the final irrigation. Nevertheless, a new technique has recently been proposed for improving removal of smear layer and debris from the root canal, whereby the irrigant is activated each time a file is removed from the root canal, and an irrigant is used. ${ }^{40}$ This approach has shown good results, but more studies are needed to provide a more definite conclusion $^{40}$. Moreover, other studies should be devised to assess possible dentin erosion caused by the action of the metal tip used for PUI procedures. ${ }^{41,42}$

Based on the findings obtained herein, it remains clear that more in vitro studies should be performed using microCT analysis, and that they should also include control and experimental groups with standardized protocols, so as to enable greater reliability in future comparisons.

\section{Conclusion}

Considering the limitations of the present study, although no irrigation protocols are able to completely free the root canal system of AHTD, this systematic review showed that final irrigation protocols with passive ultrasonic irrigation were more effective than non-activated irrigation in removing such debris. The findings presented in this study reinforce the concept that PUI can increase residue removal and improve the cleanliness of root canals in endodontic treatment.

\section{References}

1. Chuppani DA, Navabi M, Rakhshan V. Isthmuses, accessory canals, and the direction of root curvature in permanent mandibular first molars: an in vivo computed tomography study. Restor Dent Endod. 2020 Feb;45(1):E7. https://doi.org/10.5395/rde.2020.45.e7

2. Iandolo A, Abdellatif D, Amato M, Pantaleo G, Blasi A, Franco V, et al. Dentinal tubule penetration and root canal cleanliness following ultrasonic activation of intracanal-heated sodium hypochlorite. Aust Endod J. 2020 Aug;46(2):204-9. https://doi.org/10.1111/aej.12393

3. Paqué F, Laib A, Gautschi H, Zehnder M. Hard-tissue debris accumulation analysis by high-resolution computed tomography scans. J Endod. 2009 Jul;35(7):1044-7. https://doi.org/10.1016/i.joen.2009.04.026

4. De-Deus G, Marins J, Silva EJ, Souza E, Belladonna FG, Reis C, et al. Accumulated hard tissue debris produced during reciprocating and rotary nickel-titanium canal preparation. J Endod. 2015 May;41(5):676-81. https://doi.org/10.1016/i.joen.2014.11.028

5. De-Deus G, Reis C, Beznos D, Abranches AM, Coutinho-Filho T, Paciornik S. Limited ability of three commonly used thermoplasticized gutta-percha techniques in filling oval-shaped canals. J Endod. 2008 Nov;34(11):1401-5. https://doi.org/10.1016/i.joen.2008.08.015 
- Effect of passive ultrasonic irrigation on hard tissue debris removal: a systematic review and meta-analysis

6. Paqué F, Al-Jadaa A, Kfir A. Hard-tissue debris accumulation created by conventional rotary versus self-adjusting file instrumentation in mesial root canal systems of mandibular molars. Int Endod J. 2012 May;45(5):413-8. https://doi.org/10.1111/j.1365-2591.2011.01991.x

7. Ricucci D, Siqueira Junior JF, Bate AL, Pitt Ford TR. Histologic investigation of root canal-treated teeth with apical periodontitis: a retrospective study from twenty-four patients. J Endod. 2009 Apr;35(4):493-502. https://doi.org/10.1016/i.joen.2008.12.014

8. Versiani MA, Alves FR, Andrade-Junior CV, Marceliano-Alves MF, Provenzano JC, Rôças IN, et al. Micro-CT evaluation of the efficacy of hard-tissue removal from the root canal and isthmus area by positive and negative pressure irrigation systems. Int Endod J. 2016 Nov;49(11):1079-87. https://doi.org/10.1111/iej.12559

9. Sluis LW, Versluis M, Wu MK, Wesselink PR. Passive ultrasonic irrigation of the root canal: a review of the literature. Int Endod J. 2007 Jun; 40(6):415-26. https://doi.org/10.1111/j.1365-2591.2007.01243.x

10. Kato AS, Cunha RS, CES, Pelegrine RA, Fontana CE, Martin AS. Investigation of the efficacy of passive ultrasonic irrigation versus irrigation with reciprocating activation: an environmental scanning electron microscopic study. J Endod. 2016 Apr;42(4):659-63. https://doi.org/10.1016/i.joen.2016.01.016

11. Ahmad M, Pitt Ford TJ, Crum LA. Ultrasonic debridement of root canals: acoustic streaming and its possible role. J Endod. 1987 Oct;13(10):490-9. https://doi.org/10.1016/S0099-2399(87)80016-X

12. Dutner J, Mines P, Anderson A. Irrigation trends among American Association of Endodontists members: a web-based survey. J Endod. 2012 Jan;38(1):37-40. https://doi.org/10.1016/j.joen.2011.08.013

13. Virdee SS, Seymour DW, Farnell D, Bhamra G, Bhakta S. Efficacy of irrigant activation techniques in removing intracanal smear layer and debris from mature permanent teeth: a systematic review and meta-analysis. Int Endod J. 2018 Jun;51(6):605-21. https://doi.org/10.1111/iej.12877

14. Lee SJ, Wu MK, Wesselink PR. The effectiveness of syringe irrigation and ultrasonics to remove debris from simulated irregularities within prepared root canal walls. Int Endod J. 2004 Oct;37(10):672-8. https://doi.org/10.1111/j.1365-2591.2004.00848.x

15. Duque JA, Duarte MA, Canali LC, Zancan RF, Vivan RR, Bernardes RA, et al. Comparative effectiveness of new mechanical irrigant agitating devices for debris removal from the canal and isthmus of mesial roots of mandibular molars. J Endod. 2017 Feb;43(2):326-31. https://doi.org/10.1016/i.joen.2016.10.009

16. Căpută PE, Retsas A, Kuijk L, Chávez de Paz LE, Boutsioukis C. Ultrasonic irrigant activation during root canal treatment: a systematic review. J Endod. 2019 Jan;45(1):31-44.e13. https://doi.org/10.1016/i.joen.2018.09.010

17. Paqué F, Boessler C, Zehnder M. Accumulated hard tissue debris levels in mesial roots of mandibular molars after sequential irrigation steps. Int Endod J. 2011 Feb;44(2):148-53. https://doi.org/10.1111/i.1365-2591.2010.01823.x

18. Freire LG, Iglecias EF, Cunha RS, Santos M, Gavini G. Micro-computed tomographic evaluation of hard tissue debris removal after different irrigation methods and its influence on the filling of curved canals. J Endod. 2015 Oct;41(10):1660-6. https://doi.org/10.1016/i.joen.2015.05.001

19. Rico-Romano C, Zubizarreta-Macho Á, Baquero-Artigao MR, Mena-Álvarez J. An analysis in vivo of intracanal bacterial load before and after chemo-mechanical preparation: A comparative analysis of two irrigants and two activation techniques. J Clin Exp Dent. 2016 Feb;8(1):e9-13. https://doi.org/10.4317/jced.52585

20. De-Deus G, Belladonna FG, Zuolo AS, Perez R, Carvalho MS, Souza EM, et al. Micro-CT comparison of XP-endo Finisher and passive ultrasonic irrigation as final irrigation protocols on the removal of accumulated hard-tissue debris from oval shaped-canals. Clin Oral Investig. 2019 Jul;23(7):3087-93. https://doi.org/10.1007/s00784-018-2729-y

21. Hülsmann M, Peters OA, Dummer PM. Mechanical preparation of root canals: shaping goals, techniques and means. Endod Topics. 2005;10(1):30-76. https://doi.org/10.1111/j.1601-1546.2005.00152.x

22. De-Deus G, Reis C, Paciornik S. Critical appraisal of published smear layer-removal studies: methodological issues. Oral Surg Oral Med Oral Pathol Oral Radiol Endod. 2011 Oct;112(4):531-43. https://doi.org/10.1016/j.tripleo.2011.01.046

23. Keleş A, Alçin H, Sousa-Neto MD, Versiani MA. Supplementary steps for removing hard tissue debris from isthmus-containing canal systems. J Endod. 2016 Nov;42(11):1677-82. https://doi.org/10.1016/i.joen.2016.07.025

24. De-Deus G, Marins J, Neves AA, Reis C, Fidel S, Versiani MA, et al. Assessing accumulated hard-tissue debris using micro-computed tomography and free software for image processing and analysis. J Endod. 2014 Feb;40(2):271-6. https://doi.org/10.1016/i.joen.2013.07.025

25. Sarkis-Onofre R, Skupien JA, Cenci MS, Moraes RR, Pereira-Cenci T. The role of resin cement on bond strength of glass-fiber posts luted into root canals: a systematic review and meta-analysis of in vitro studies. Oper Dent. 2014 Jan-Feb;39(1):E31-44. https://doi.org/10.2341/13-070-LIT

26. Rosa WL, Piva E, Silva AF. Bond strength of universal adhesives: A systematic review and meta-analysis. J Dent. 2015 Jul;43(7):765-76. https://doi.org/10.1016/i.jdent.2015.04.003

27. Silva EJ, Rover G, Belladonna FG, De-Deus G, da Silveira Teixeira C, da Silva Fidalgo TK. Impact of contracted endodontic cavities on fracture resistance of endodontically treated teeth: a systematic review of in vitro studies. Clin Oral Investig. 2018 Jan;22(1):109-18. https://doi.org/10.1007/s00784-017-2268-y 
28. Borenstein M, Hedges LV, Higgins JP, Rothstein HE. Introduction to meta-analysis. Chichester: John Wiley \& Sons; 2009. https://doi.org/10.1002/9780470743386

29. Rödig T, Koberg C, Baxter S, Konietschke F, Wiegand A, Rizk M. Micro-CT evaluation of sonically and ultrasonically activated irrigation on the removal of hard-tissue debris from isthmus-containing mesial root canal systems of mandibular molars. Int Endod J. 2019 Aug;52(8):1173-81. https://doi.org/10.1111/iej.13100

30. Leoni GB, Versiani MA, Silva-Sousa YT, Bruniera JF, Pécora JD, Sousa-Neto MD. Ex vivo evaluation of four final irrigation protocols on the removal of hard-tissue debris from the mesial root canal system of mandibular first molars. Int Endod J. 2017 Apr;50(4):398-406. https://doi.org/10.1111/iej.12630

31. Zhao Y, Fan W, XU T, Tay FR, Gutmann JL, Fan B. Evaluation of several instrumentation techniques and irrigation methods on the percentage of untouched canal wall and accumulated dentine debris in C-shaped canals. Int Endod J. 2019 Sep;52(9):1354-65. https://doi.org/10.1111/iej.13119

32. Teixeira FB, Sano CL, Gomes BP, Zaia AA, Ferraz CC, Souza-Filho FJ. A preliminary in vitro study of the incidence and position of the root canal isthmus in maxillary and mandibular first molars. Int Endod J. 2003 Apr;36(4):276-80. https://doi.org/10.1046/j.1365-2591.2003.00638.x

33. Endal U, Shen Y, Knut A, Gao Y, Haapasalo M. A high-resolution computed tomographic study of changes in root canal isthmus area by instrumentation and root filling. J Endod. 2011 Feb;37(2):223-7. https://doi.org/10.1016/j.joen.2010.10.012

34. Silva EJ, Carvalho CR, Belladonna FG, Prado MC, Lopes RT, De-Deus G, et al. Micro-CT evaluation of different final irrigation protocols on the removal of hard-tissue debris from isthmus-containing mesial root of mandibular molars. Clin Oral Investig. 2019 Feb;23(2):681-7. https://doi.org/10.1007/s00784-018-2483-1

35. Silva EJ, Rover G, Belladonna FG, Herrera DR, De-Deus G, Fidalgo TKS. Effectiveness of passive ultrasonic irrigation on periapical healing and root canal disinfection: a systematic review. Br Dent J. 2019 Aug;227(3):228-34. https://doi.org/10.1038/s41415-019-0532-z

36. Guerreiro MY, Belladonna FG, Monteiro LP, Lima CO, Silva EJ, Brandão JM. The influence of the addition of surfactants to sodium hypochlorite on the removal of hard tissue debris. Int Endod J. 2020 Aug;53(8):1131-9. https://doi.org/10.1111/iej.13307

37. Alves FR, Paiva PL, Marceliano-Alves MF, Cabreira LJ, Lima KC, Siqueira Junior JF, et al. Bacteria and hard tissue debris extrusion and intracanal bacterial reduction promoted by XP-endo Shaper and Reciproc Instruments. J Endod. 2018 Jul;44(7):1173-8. https://doi.org/10.1016/i.joen.2018.04.007

38. Orlowski NB, Schimdt TF, Teixeira CD, Garcia LD, Savaris JM, Tay FR, et al. Smear layer removal using passive ultrasonic irrigation and different concentrations of sodium hypochlorite. J Endod. $2020 \mathrm{Jul}$;6(11) :S0099-2399(20)30509-4. https://doi.org/10.1016/i.joen.2020.07.020

39. Perez R, Neves AA, Belladonna FG, Silva EJ, Souza EM, Fidel S, et al. Impact of needle insertion depth on the removal of hard-tissue debris. Int Endod J. 2017 Jun;50(6):560-8. https://doi.org/10.1111/iej.12648

40. Plotino G, Colangeli M, Özyürek T, DeDeus G, Panzetta C, Castagnola R, et al. Evaluation of smear layer and debris removal by stepwise intraoperative activation (SIA) of sodium hypochlorite. Clin Oral Investig. 2021 Jan;25(1):237-45. https://doi.org/10.1007/s00784-020-03358-6

41. Lea SC, Felver B, Landini G, Walmsley AD. Ultrasonic scaler oscillations and tooth-surface defects. J Dent Res. 2009 Mar;88(3):229-34. https://doi.org/10.1177/0022034508330267

42. Simezo AP, da Silveira Bueno CE, Cunha RS, Pelegrine RA, Rocha DG, Martin AS, et al. Comparative analysis of dentinal erosion after passive ultrasonic irrigation versus irrigation with reciprocating activation: an environmental scanning electron study. J Endod. 2017 Jan;43(1):141-6. https://doi.org/10.1016/i.joen.2016.09.016 